2002s-17

\title{
The Choice of Instruments for Environmental Policy: Liability or Regulation?
}

Marcel Boyer, Donatella Porrini

Forthcoming in Timothy Swanson (ed.), An Introduction to the Law and Economics of Environmental Policy : Issues in Institutional Design, Research in Law and Economics Series Vol.20, 2002, Elsevier Science Ltd.

Série Scientifique

Scientific Series
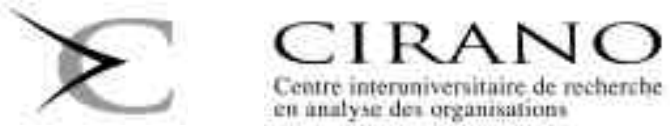

Montréal

Février 2002 


\section{CIRANO}

Le CIRANO est un organisme sans but lucratif constitué en vertu de la Loi des compagnies du Québec. Le financement de son infrastructure et de ses activités de recherche provient des cotisations de ses organisationsmembres, d'une subvention d'infrastructure du ministère de la Recherche, de la Science et de la Technologie, de même que des subventions et mandats obtenus par ses équipes de recherche.

CIRANO is a private non-profit organization incorporated under the Québec Companies Act. Its infrastructure and research activities are funded through fees paid by member organizations, an infrastructure grant from the Ministère de la Recherche, de la Science et de la Technologie, and grants and research mandates obtained by its research teams.

\section{Les organisations-partenaires / The Partner Organizations}

-École des Hautes Études Commerciales

-École Polytechnique de Montréal

-Université Concordia

-Université de Montréal

-Université du Québec à Montréal

-Université Laval

-Université McGill

-Ministère des Finances du Québec

-MRST

-Alcan inc.

- AXA Canada

-Banque du Canada

-Banque Laurentienne du Canada

-Banque Nationale du Canada

- Banque Royale du Canada

- Bell Canada

- Bombardier

- Bourse de Montréal

-Développement des ressources humaines Canada (DRHC)

-Fédération des caisses Desjardins du Québec

-Hydro-Québec

-Industrie Canada

-Pratt \& Whitney Canada Inc.

-Raymond Chabot Grant Thornton

-Ville de Montréal

(C) 2002 Marcel Boyer et Donatella Porrini. Tous droits réservés. All rights reserved. Reproduction partielle permise avec citation du document source, incluant la notice (C).

Short sections may be quoted without explicit permission, if full credit, including (C) notice, is given to the source.

Les cahiers de la série scientifique (CS) visent à rendre accessibles des résultats de recherche effectuée au CIRANO afin de susciter échanges et commentaires. Ces cahiers sont écrits dans le style des publications scientifiques. Les idées et les opinions émises sont sous l'unique responsabilité des auteurs et ne représentent pas nécessairement les positions du CIRANO ou de ses partenaires.

This paper presents research carried out at CIRANO and aims at encouraging discussion and comment. The observations and viewpoints expressed are the sole responsibility of the authors. They do not necessarily represent positions of CIRANO or its partners.

\section{ISSN 1198-8177}




\title{
The Choice of Instruments for Environmental Policy: Liability or Regulation?
}

\author{
Marcel Boyer ${ }^{*}$ and Donatella Porrini ${ }^{\dagger}$
}

\author{
Résumé / Abstract
}

Dans cet article, nous comparons différents instruments visant une protection efficace contre la dégradation de l'environnement, une couverture efficace des dommages et une compensation convenable aux victimes. Nous considérons deux instruments principaux, à savoir un régime de réglementation incitative et un régime de responsabilité légale en cas de dommages environnementaux, tel qu'on le trouve dans le CERCLA américain et le White Paper européen qui comportent des provisions de responsabilité élargie. Nous développons une approche analytique structurée et formelle à la modélisation des interactions économiques entre les différents décideurs que sont les gouvernements, les entreprises, les régulateurs et les financiers.

We address in this paper the problem of comparing and choosing among different policy instruments to implement the incentive objective of an efficient deterrence of environmental degradation and the remedy objective of an efficient clean-up of damages and a proper compensation of victims. Two main instruments are considered, namely the assignment of legal liability for environmental damage, such as in the American CERCLA and in the European White Paper, including extended liability provisions, and the design of an incentive regulation framework. Our results derive from a formal and structured analytical approach to modeling the economic interactions between different decision makers such as governments, firms, regulators and financiers.

Mots-clés : Politique environnementale, responsabilité élargie, capture des régulateurs, choix d'instruments

Keywords: Environmental policy, extended liability, regulatory capture, instrument choice

JEL: K32, L51, P16, Q28

\footnotetext{
* Department of Economics and CIRANO, Université de Montréal [marcel.boyer@cirano.qc.ca]

${ }^{\dagger}$ Facoltà di Giurisprudenza, Università degli Studi di Milano [donatella.porrini@unimib.it]
} 


\section{Introduction}

Different policies have been considered to implement a proper internalization of environmental externalities: taxes, quotas, subsidies, marketable emission permits, assignment of liabilities, etc. This addresses directly the problem of comparing and choosing among different policy instruments to implement a given set of environmental protection objectives. ${ }^{1}$ Considering a law and economics approach, the chosen instrument must address an incentive objective (the efficient deterrence of environmental degradation) and a remedy objective (the efficient clean-up of damages and the proper compensation of victims).

We intend to compare in this paper two instruments, namely the assignment of legal liability for environmental damage and the design of an incentive regulation framework in the context of a political economy theory of environmental policy. A system of liability assignment can provide compensation to victims while internalizing the social costs of harm producing activities, ${ }^{2}$ by identifying the cause of environmental harms, assessing the behavior of the actors responsible for such harms, and quantifying the harms for plaintiffs.

In a world of perfect or at least complete information, the law and economics approach suggests that this first instrument is an efficient method to solve the problem of internalizing the potential effects of environmental accidents. Ex ante, the firm, its owners and operators, face the proper incentive to take the efficient level of precaution and ex post, the individuals harmed by pollution

\footnotetext{
${ }^{1}$ See Buchanan and Tullock (1975), Yohe (1976), Boyer (1979), Noll (1983), Hahn (1990), Cropper and Oates (1992), Laffont (1995), Segerson (1996) and Lewis (1996).

${ }^{2}$ See Calabresi (1970); Landes, Posner, (1987); Shavell (1987).
} 
receive a proper and complete compensation, possibly through an insurance provider. But in practice, the allocation of individual responsibility seems to have caused delay in the clean up of damaged sites and contributed little to the objective of deterrence, ${ }^{3}$ in particular when “judgement-proof” firms were involved. ${ }^{4}$

The following reasons have been suggested to explain this result. First, a specific polluter could in many cases be difficult to identify. A disease or a reduction in health could be attributed to a number of different factors besides the pollution. Even if a link between a pollutant and the disease could be established, it turned out to be difficult in many cases to determine which firm was responsible for the damage. Second, compulsory insurance contracts that the firms were induced or forced to buy turned out to be incomplete or insufficient because it was in many cases difficult to determine the probability of accident and the distribution of the loss caused by environmental accidents, ${ }^{5}$ hence making the pricing of the contracts more difficult. Third, the polluter ended up in some cases to be insolvent and unable to pay for clean-up or compensation costs because of an increasing number of smaller firms operating in dangerous activities and because of the increasing costs and penalties of environmental accidents. Moreover, additional problems can arise in an incomplete information context, as analyzed by the economic literature: the asymmetric information about the firm's technology or accident preventing efforts implies that a rent must be given up to the stakeholders of the firm and the choice of a specific environmental policy affects this rent.

\footnotetext{
${ }^{3}$ See Menell (1991).

${ }^{4}$ See Shavell (1986).

${ }^{5}$ See Priest (1987).
} 
For all these reasons reducing the efficiency of a liability assignment system, it is appropriate to consider alternative instruments such as a regulatory framework. Of course this second instrument can present similar problems of implementation, such as informational problems (very often the level of effort to reduce the probability of environmental accidents is a private information of the firm) and capture problem (the regulator is often subject to "influence" by the firm itself or by political pressure). The problem is then to determine the circumstances or situations in which one instrument is better than the other.

\section{The problem of the choice of instruments}

As a result of the large number of instruments that have been considered to implement a given set of environmental policy objectives, the relative efficiency of these policy instruments has become an important question in environmental economics, as shown by the recent surveys of Cropper and Oates (1992), Segerson (1996) and Lewis (1997). Although most of the discussions of the choice of instruments still use a benevolent social welfare maximizer paradigm, the necessity of looking at political economy factors underlying the choice of instruments has gained some ground at least since the early contribution of Buchanan and Tullock (1975). However, dissatisfaction remains. Lewis (1997, p. 844) wrote: "I see the next progression in [environmental regulation] as being a positive analysis asking which kind of environmental policies will be implemented under information and distribution constraints when special interests try to intervene to affect policy."

Boyer and Laffont (1999) provided some preliminary steps in developing a formal political economy of environmental economics. They argued that economists' general preferences for sophisticated incentive regulation mechanisms must be reconsidered in a political economy 
approach explicitly considering the private information of economic agents, giving rise to policy sensitive and socially costly informational rents, and the incomplete contract nature of constitutions. When the different parties can contract without constraints, we know from the Revelation Principle that any policy instrument is equivalent to a revelation mechanism which is typically a command and control procedure. In such a mechanism, the different agents communicate truthfully their private information to an authority who then recommends proper actions. Once an optimal revelation mechanism has been obtained, it can be implemented through various policy instruments or institutions which by definition implement the same allocation. Hence, the question of instrument choice in such a context is empty. ${ }^{6}$

Nevertheless, the choice between instruments remain a meaningful problem insofar as one assumes the existence of constraints on instruments or of constraints on contracting possibilities. In the first case, various constrained instruments can be compared. ${ }^{7}$ In the second case, different instruments, equivalent in a complete contracting framework, have different impacts when imperfections elsewhere in the economy are introduced. ${ }^{8}$

A systematic analysis of instrument choice in environmental policy should then be conducted in well defined second best frameworks, all of which are shortcuts of an incomplete contract analysis. Political economy features can be viewed as a special case of this methodology. This is

\footnotetext{
${ }^{6}$ Boyer and Laffont (1999) mentioned that "such a question often arose in the literature because authors were not careful enough in defining their instruments. For example, Yohe (1976) correctly shows that the alleged difference between quotas and price controls in Buchanan and Tullock (1975) disappears when instruments are appropriately defined."

7 As argued by Boyer and Laffont (1999), this is the case of Weitzman's (1974) comparison of prices and quantities. Asymmetric information then calls for non-linear prices as optimal instruments. Another example is the case of non-convexities where linear taxes are dominated by quotas because quotas are in fact non-linear taxes.

${ }^{8}$ As argued by Boyer and Laffont (1999), "this is the case in Buchanan's (1969) example of a polluting monopolist when the subsidies required to correct the monopolistic behavior are not available." The linear tax is then clearly dominated by a quota implementing the second best tax.
} 
the object of our comparison between two major instruments: a legal instrument based on an extended liability framework for environmental damage and a regulatory instrument based on an incentive regulation framework subject to capture by the regulated firms. In both case, asymmetric information (moral hazard) is assumed making the first best allocation infeasible.

In the next two sections, we consider and discuss a real case application of the first instrument consisting in assigning a CERCLA (Comprehensive Environmental Response, Compensation and Liability Act 1980, 1985, 1996) type liability, typically a strict, joint and several liability, on the owners and operators of the firm that is responsible of a catastrophic environmental disaster. In the following sections, we will tackle the analysis of regulatory instruments and the comparison of instruments.

\section{The liability systems: U.S. CERCLA and European White Paper}

In the eighties, the U.S. Congress enacted CERCLA and created a Superfund for the quick and effective clean-up of dangerous waste sites. ${ }^{9}$ The U.S. liability system for environmental damages is a system that considers all owners and operators retroactively, strictly, jointly and severally liable for all damages through a system of extended liability. In spite of a secured interest exemption clause protecting financial institutions, holding indicia of ownership on the firm's assets, the U.S. courts have repeatedly considered secured lenders as owners or operators, insofar as their involvement in the operations of the firm exceeded the level warranted to secure their interest. This critical level was lowered over time and lenders' liability turned out to be more common than expected or intended. 
A form of lenders' liability system was defined by the courts decisions, for example through the following cases: United States v. Mirabile, United States v. Maryland Bank \& Trust, United States v. Fleet Factors, and Bergsoe Metal v. East Asiatic. Also important in the definition of the extended liability system was the 1992 EPA so-called Final Rule which attempted to make more precise the scope of traditional lender activities avoiding Superfund liabilities and leading to the 1996 CERCLA amendments.

Another experience of extended liability, to overcome the problem of judgment-proof firms, was the financial responsibility solution. By some rules, the potential polluters were required to demonstrate financial resources adequate to compensate for the environmental damage that they could cause. A financial assurance rule was for example authorized both by CERCLA and OPA (Oil Pollution Act) for waterborne vessels that carry oil or hazardous substances. ${ }^{10}$ We can find such applications of the financial responsibility solution in many activities: in off-shore oil facilities; in underground petroleum storage tanks; solid waste landfills; in hazardous waste treatment, storage and disposal facilities; in wells to protect drinking water quality; in coal and hardrock mines; and in nuclear reactors and radioactive disposal facilities. ${ }^{11}$

The U.S. liability system, administered by the courts and governed principally by state law, played an extensive role in regulating air pollution, water pollution, hazardous and solid waste disposal, and pesticide use, among other environmental risks. It provides a mechanism for compensating victims, property, and health injuries by a strict liability system. Alongside the tort

\footnotetext{
${ }^{9}$ The Superfund enabled the government to begin cleaning-up of priority sites placed on the National Priority List (NPL) with money generated principally by taxes on cruel oil, corporate income, petro-chemical feedstocks, and motor fuels.

${ }^{10}$ 33, USC $§ 2702$; 42 USC $\S 9607$ (a)(1). Codified in: 33 CFR, part 138

${ }^{11}$ See Boyd (2001).
} 
system, there exist a system of private and public insurance, both for the firms' liability and for the consequences on individual health.

But the U.S. CERCLA liability system raised also many problems. First of all many potentially responsible parties can be involved and, although it could be appropriate to divide among polluting parties the amount of needed compensation, this creates incentive problems insofar as the strict and joint liability system can induce firms to devote resources to legal strategies rather than to prevent accidents. In any case, it is difficult to coordinate numerous parties with conflicting interests and to find an agreement on a cost allocation plan. Moreover, since the government must recover response cost by suing all the potentially responsible parties or by targeting some "deep pocket” ones, significant transaction costs may result.

In addition to this transaction cost problem, CERCLA liability system was not supported by a significant development of the insurance market. ${ }^{12}$ Insurance policies covering lending institutions in case of environmental accident turn out in many case to be unavailable or prohibitively expensive to obtain. Of course, the unavailability and the high cost of these kinds of policy are connected with the fact that the potential liability remain difficult to ascertain given the roles played by the EPA, the courts or the Congress. Federal court decisions have pointed out the effects of this problem. First, the insurance policies typically do not fit the CERCLA retroactive liability system because they are claims-made policies in the sense that they cover claims made while the policies are in effect and not the claims made before or after the period for which the insurance contract is in force. Second, both the premium and the deductible in the policies are

\footnotetext{
${ }^{12}$ See Staton, (1993).
} 
extremely high, only a few insurance companies in the US have issued such policies and many lending institutions have opted for self-insurance. ${ }^{13}$

The European Community has been trying for many years to define a common system of assignment of liability for environmental damages. In 1993, the European Commission published the Green Paper on Remedying Environmental Damage. ${ }^{14}$ It presented the broad concepts on which a liability system could be built and led to discussions on the future EC liability regime. Its purpose was not to establish the elements of a specific unified system, but to stimulate a Community wide debate and also collect the opinions of the interested parties. The Green Paper contained a description of the issues relevant to designing a Community-wide liability system. It focused on the liability criteria, the definition of environmental damage, the insurability of environmental damage, the limitations of liability, the problem of reinstatement of the environment, and the possibility of compensation funds financed by industries.

In the same year, the Commission explored the concept of the EC joining the 1993 Council of Europe Lugano Convention, but a definitive decision did not follow because of the intention to issue a specific White Paper and a proposal of Directive. In November 1997, the Working Paper on Environmental Liability outlined the key elements of a proposed environmental liability directive $^{15}$ and in October 1998, a commitment to adopt a White Paper on Environmental Liability was stated. ${ }^{16}$ The Commission published a detailed environmental liability model for

\footnotetext{
${ }^{13}$ A. Johnson \& Co. v. Aetna Casuality \& Sur. Co., 933 F.2d 66 (1st Cir. 1991); United States Fidelity \& Guar. Co. v. George W. Whitesides Co., 932 F..2d 1169 ( $6^{\text {th }}$ Cir. 1991).

${ }^{14}$ Commission of European Communities, Communication from the Commission of the Council and Parliament: Green Paper on Remedying Environmental Damage, COM (93) 47 final, Brussels, 14 may 1993, OJ 1993 C 149/12.

${ }^{15}$ Commission of European Communities, Working Paper on Environmental Liability, 17 November 1997.

${ }^{16}$ Commission Decision 2176/98 (24/9/98) on the review of policy and action in relation to the environment and sustainable development, “Towards Sustainability”, OJ 1998 L 275/12.
} 
the EC in March $1999^{17}$ and finally the White Paper on Environmental Liability in February $2000 .^{18}$

The White Paper aims at determining who should pay for the clean-up and restoration costs of the environmental damage resulting from human acts. The question whether the costs should be paid by society at large, through the tax system, or by the polluter, when it can be identified, was answered by the imposition of liability on the party responsible for causing such damage. ${ }^{19}$ The liability system is essentially a strict (no-fault) and non-retroactive liability system. Liability is only effective for future damage where polluters can be identified, damage is quantifiable and a causal connection can be shown. The Commission justifies the choice of such a system as follows. First, the "polluter pays principle" is more efficiently applied if the polluter must pay for the damages regardless of fault. Second, the operator of an hazardous activity should bear the risk inherent in it. Third, it can be difficult for the victims to prove the fault of the operator because of a lack of knowledge. Fourth, a non-retroactive system allows a quicker consensus by restricting attention on care for future accident prevention only.

Given the general rule that the polluter must always be the first actor a claim is addressed to, the White Paper does not explicitly deal with the problem of lender's liability. But it states that the person (or persons) who exercises control of an activity by which the damage is caused (namely the operator), should be the liable party, with the specification that lenders not exercising operational control should not be liable. In the final part of the White Paper that deals with the overall economic impact of environmental liability in the European Community, it is stated that

\footnotetext{
17 The draft is an internal document of the Commission of European Communities not officially published, presented by DG XI in March 1999.
} 
the liability system generally protects economic operators in the financial sectors, unless they have operational responsibilities. The application of the financial responsibility in the common environmental liability system in Europe is not very well defined. For example, insurance markets are seen, in the White Paper, as one of the possible ways to obtain financial security, together with bank guarantees and internal reserves, but the European insurance system is still considered in a sense underdeveloped and unable to offer this kind of solution. So the Commission explicitly affirms "the EC regime should not impose an obligation to have financial security" (point 4.9).

The main differences between the provisions in the U.S. CERCLA system and the ones in the White Paper are summarized in TABLE 1.

${ }^{18}$ Commission of European Communities, "White Paper on Environmental Liability", COM (2000), 66 final, Brussels, 9 February, 2000.

${ }^{19}$ See Pozzo (2000). 
TABLE 1

\begin{tabular}{|c|c|c|}
\hline FEATURES & $\begin{array}{l}\text { U.S. CERCLA } \\
\text { PROVISIONS }\end{array}$ & $\begin{array}{l}\text { E.C. WHITE PAPER } \\
\text { PROVISIONS }\end{array}$ \\
\hline REGIME OF LIABILITY & Strict liability & Strict liability \\
\hline APPLICATION & Retroactivity & No retroactivity \\
\hline LIABLE PARTIES & $\begin{array}{l}\text { Several and joint } \\
\text { liability }\end{array}$ & $\begin{array}{c}\text { Mitigated several and joint } \\
\text { liability }\end{array}$ \\
\hline DAMAGE & $\begin{array}{l}\text { Every damage, even } \\
\text { damages to natural } \\
\text { resources }\end{array}$ & $\begin{array}{l}\text { Traditional damages and the } \\
\text { contamination of sites }\end{array}$ \\
\hline FUND & $\begin{array}{l}\text { Creation of a } \\
\text { Superfund to finance } \\
\text { cleaning-up }\end{array}$ & No special fund created. \\
\hline LENDER'S LIABILITY & $\begin{array}{l}\text { Many applications } \\
\text { by the courts. }\end{array}$ & No application. \\
\hline $\begin{array}{c}\text { FINANCIAL } \\
\text { RESPONSIBILITY }\end{array}$ & $\begin{array}{l}\text { Many applications } \\
\text { for many activities. }\end{array}$ & Excluded for the time being \\
\hline
\end{tabular}


We can see that the EC White Paper liability system is similar to the US system because both of them are based on a strict liability regime in the sense that the liability is assigned only on the basis of the fact that the actor has caused the damage, without reference to the actor's behavior, diligence or negligence. But they are also different in many aspects: while the CERCLA system is applied retroactively, the EC White Paper provide a non-retroactive application; instead of covering every damage including the damage to natural resources, the European system covers only traditional damages, such as personal injury, damage to property, and the decontamination of sites; in the US system, the Superfund was created to quickly clean-up the environmental damage, while no such fund is established by the White Paper. Differences exist also in the definition of lender liability and financial responsibility.

\section{The economic analysis of the extended environmental liability system}

We complete the description of the liability system applied in U.S. and in Europe by considering in this section the major analytical contributions to the study of extending liability to lenders, in terms both of its capacity to induce a proper internalization of environmental risks and of its capacity to ensure the proper financing of environmentally risky activities.

The economic analysis of extending liability to lenders as an environmental policy relies in good part on the incomplete (asymmetric) information principal agent paradigm, where the lender is the principal and the firm is the agent. ${ }^{20}$ In those contexts, the firm is assumed to have private information about the cost of carrying out a task or project (adverse selection) and/or about how much self-protection or preventive effort it chooses to undertake (moral hazard) to reduce the

\footnotetext{
${ }^{20}$ See Pitchford (1995); Boyer, Laffont (1996, 1997).
} 
probability of environmental disasters. ${ }^{21}$ The analyses allow for the comparison of the different levels of care and of financing emerging in the different liability systems. ${ }^{22}$ Those analyses lead to an evaluation of the predicted impacts of the different liability regimes in terms of social welfare. The benefits in terms of better accident prevention care and of better financing of risky activities must be compared with the cost of care, the system administrative expenses and the expected level of the damages, that is, both the expected number of accidents and their severity.

Pitchford (1995) raised the question of how appropriate extending liability to the lender is, given that under asymmetric information it is likely to change the financial contracts offered to the firm. A limited liability regime reduces the firm's benefits of taking precautions to reduce the probability of accident. On the other hand, the lenders made liable for the cost of accident will require a form of insurance premium as part of the cost of financing to compensate them for their expected liability level. So extending liability to lenders increases the probability of proper compensation for external victims of an accident but may increase the probability of accident since the insurance premium reduces the wedge between the firm's relative value in the two possible states of the world, accident or no accident. Pitchford concludes by suggesting that, if the lender cannot observe the precautionary behavior of the firm under a limited liability regime, then increasing the liability of the lender can lead to an increase in the probability of accident. A better compensation system is thus obtained at the expense of a larger probability of accident. ${ }^{23}$

\footnotetext{
${ }^{21}$ See Porrini (2001).

22 The law and economics literature per se has focused predominantly on the role of institutions and common law rules in achieving efficiency and distributive goals (Calabresi, 1970; Polinsky 1980; Landes and Posner, 1987; Shavell, 1987; Tietenberg 1989; Kornhauser and Revesz, 1994; Segerson and Tietenberg 1992). In this approach, extended liability has been analyzed in terms both of its capacity to provide (ex ante) incentives to avoid environmental degradation and of its capacity to ensure (ex post) the proper compensation of victims. The courts are then ultimately responsible for meeting these objectives.

${ }^{23}$ The contribution of Pitchford was recently criticized by Balkenborg (2001) who stresses the critical role of relative bargaining power in determining when lenders liability can increase the probability of accident, and by
} 
Boyer and Laffont (1997) consider a situation with both moral hazard and adverse selection in a model with two principals, a lender and an insurer. In a typical situation, the firm has better knowledge of its profit potential and of its accident prevention activities than the lenders or the insurers and extending liability modifies lending conditions and financial contracting between a firm and a lender. Under complete information between lender and firm but incomplete between insurer and firm, a regime of extended full liability to the lender when the firm goes bankrupt is optimal both for lending level and for the accident prevention or safety level. The relation with the CERCLA system and the related jurisprudence, allocating responsibility according to the involvement of the bank into the management of the firm, is clear: the assignment of full extended liability is appropriate as long as the risks are well defined and the agency costs are small.

If the firm's profit level is not observable by the lenders but the firm's accident preventing activities are observable, the financial contract cannot depend on profits and the best liability regime for lenders is a partial extended one. Extending full responsibility for environmental damages to the lender would ensure a perfect internalization but leads to insufficient lending. The result is obtained in three steps. First, the authors characterize the financing contract that a social welfare maximizing regulator would offer to the firm. Second, they characterize the financing contract that a private profit maximizing financier would offer as a function of the extended liability rule. Third, they compare the two and make the second solution as close as possible to the first one by varying the level of lender liability.

Lewis and Sappington (2001) who stress that the damages can take more that two values, a minor change which has a significant effect on the efficiency of the lenders liability solution. See also the reply of Pitchford (2001). 
Under moral hazard, the lender can observe the profit of the firm but cannot observe its level of prevention activities and again a regime of full extended liability can cause the lender to lend too little. The optimal level of partial lender liability is a function of the characteristics of the firm and/or the project to be realized. The practical implications of the results of this analysis is that the responsibility system must be well defined ex ante because it interferes with the banks' lending policy under asymmetric information. If there are no significant agency costs, full responsibility of the bank ensure the internalization of the environmental accident costs. If agency costs are significant, partial extended liability can balance the need to internalize the risks and the reluctance of the banks to finance risky but valuable activities.

Other complementary contributions can be found in the economic literature, analyzing other aspects of extending liability to the lenders. The modeling in this field presents an increasing level of complexity in its attempt to represent real situations that can involve more than one agent and more than one principal, with particular asymmetric information problems in dynamic settings with renegotiation issues present. ${ }^{24}$ It is then possible to take into account the impact of different regimes on the structure of financial contracts, on the working of financial markets, on the availability of credit, on the cost of capital and on the level of investments and financing. ${ }^{25}$ The specific structure of asymmetric information considered is crucial for such analyses.

The economic literature on the efficiency of the financial responsibility solution is much more limited. Feess and Hege, ${ }^{26}$ in different recent contributions, tried to demonstrate that financial responsibility, as a variant of mandatory insurance, can be an efficient instrument to face the

\footnotetext{
${ }^{24}$ See among others Boyd and Ingberman (1997), Dionne and Spaeter (1998), Gobert and Poitevin (1998), Gobert (1999).

${ }^{25}$ See Heyes (1996).
} 
problem of bankruptcy of the polluter and of the consequent insufficient level of precaution incentive. They consider the following asymmetric information problem: investors have difficulties to correctly anticipate environmental risk (adverse selection) and cannot monitor the care level (moral hazard) without suffering a cost. They show that financial responsibility can be more efficient than lender liability and standard strict liability given that the contract between the firm and the lender or insurer who assume residual liability is chosen to reduce the agency cost at the minimum and that the firm is always held fully liable for the damage, regardless of the fact that the damage can be fully paid out by the firm.

\section{The incentive regulation system}

We want to review in this section the second instrument, namely an environmental regulation system. A regulation system is based on an authority or an agency that can use a number of tools to control the likelihood of an environmental accident. The instrument most often used is the setting of standards. Under a mandatory technology or abatement standard, the regulator can order the firms to reduce their emissions by a certain percentage, to emit no more than a specified amount of a pollutant, and/or to install a particular abatement technology. These are examples of command and control mechanisms. As an alternative, there are incentive market-based regulatory instruments: emission taxation, marketable permits, offset trading, and other incentive regulation mechanisms.

The command-and-control activities such as standards and emission limits are typically controlled through the conduct of inspections, actions in federal courts, and negotiated settlements with polluters. The regulator can alternatively use incentive regulation, such as a

\footnotetext{
${ }^{26}$ See Feess (1999); Feess, Hege, (2000); Feess, Hege (2001).
} 
system of tradable permits which typically works as follows: a plant or firm is allocated a number of permits, each of them allowing the emission of a given amount of a pollutant; if the facility is able to reduce its emissions, preferably through the use of different inputs or of less polluting technologies, it can sell its remaining emission permits to another facility that is unable to meet its quota.

Starting in the 70s, the U.S. regulatory regime employed a variety of approaches to address the risk of pollution trying to regulate though standards the emission of toxic substances. But the task of regulating the myriad of sources of toxic emissions overwhelmed regulatory agencies and caused many problems. ${ }^{27}$ In specific cases, some statutes provided general authority to regulate all the substances posing an environmental risk. But the problem still remained to establish clear thresholds. By subjecting standards to a feasibility constraint, Congress directed the EPA to set standards under the Clean Air act following "the best technological system of continuous emission reduction which (taking into consideration the cost of achieving such emission reduction, and any non-air quality health and environmental impact and energy requirements) has been adequately demonstrated. ${ }^{28}$ Moreover "factors relating to the assessment of the best available technology shall take into account the age of equipment and facilities involved, the process employed, the engineering aspects of the application of various types of control techniques, process changes, the cost of achieving such effluent reduction, non-water quality environmental impact (including energy requirements), and such other factors as the Administrator deems appropriate. ${ }^{29}$

\footnotetext{
${ }^{27}$ See Mennel (2000).

2842 USC $\$ 7411$ (a)(1).

2933 USC § 1314 (b) (2) (B).
} 
Given these guidelines from the Congress, a major problem still remained: how to regulate the use of chemicals for which conducting scientific tests to determine their effects on human health would take a long time and therefore would expose many people to potentially serious risk ? Given the importance of regulating the risky activities and to fix appropriate standard to control ex ante the danger of environmental disaster we can conclude by quoting the court in the case Boomer v. Atlantic Cement Co: "It seems apparent that amelioration of air pollution will depend on technical research in great depth; on a carefully balanced consideration of the economic impact of close regulation; and of the actual effect on public health. It is likely to require massive public expenditure and to demand more than any local community can accomplish and to depend on regional and interstate controls.",30

\section{The economic approach to environmental regulation}

One advantage of the regulation instrument, as argued by Boyer and Laffont (1999), is that politicians could use their detailed knowledge of the economy to choose a more flexible and adapted regulation policy. But in so doing, they could pursue their private agendas. In fact regulators can be subject to different kind of influence that makes the government regulation not always congruent to the public interest. As noted by Faure (2000), rent-seeking problems can emerge in the case of environmental regulation in many different ways such as lobby for barriers to entry or lenient standards, and this influences also the instrument choice.

In the economic literature, the early contributions to the regulation of environmental risks have considered models in which the regulator maximizes a welfare function decreasing with the level of damage and the level of abatement costs. The regulatory policy is typically formulated in a

\footnotetext{
${ }^{30}$ Boomer v. Atlantic Cement Co., 257 NE2d 870 (NY 1970).
} 
single period and remains in effect afterwards. ${ }^{31}$ More recently the literature presents models that take into account asymmetric information and delegation problems. In Laffont (1995), regulation, as an environmental policy instrument, is considered in relation with the potential trade-off between the regulatory efforts, which induce greater focus on cost minimization, and the agent's incentive to take too much risk. Laffont uses the basic model of a regulated monopoly with two types of effort variables, one that decreases production cost and one that decreases the probability of accident. The optimal regulation, under incomplete information, provides incentive for safety care and leaves a rent to more efficient firms. To mitigate the rent, safety care effort is reduced. In the absence of safety issues, the rent is the same but the level of efforts for cost minimization is lower, inducing higher costs than if such care considerations are not present. Laffont then introduces a limited liability constraint with the consequence that a rent must also be left to the least efficient firms as the only way to induce proper safety care. All the phenomena analyzed call for low powered incentive schemes: weaker incentives for cost minimization to induce safety effort at a lower social cost.

Boyer and Laffont (1999) consider the problem of choosing an environmental policy in an incomplete contract political economy context. Their model is that of a regulated monopolist who is privately informed of the cost of realizing a public project, a decreasing function of the level of pollution it is allowed to generate. Regulation may be delegated to political parties. Given the asymmetric information problem about the firm's technology, a rent must be given up to those who have stakes in the firm. The choice of an environmental policy affects this rent. Since the different political parties may be considered as having different stakes in the firm, more precisely in its informational rent, the environmental policy conducted through the regulatory

\footnotetext{
${ }^{31}$ See Roberts, Spence (1976); Kwerel (1977); Dasgupta, Hammond and Manskin (1980); Baron (1985).
} 
framework generates policy fluctuations that could be welfare reducing. The authors recast the problem of instrument choice for environmental policy in the general mechanism design literature within an incomplete contract approach to political economy. They compare different sets of alternative instruments. In each case, a cruder less flexible regulation instrument is compared with a more sophisticated market-based incentive regulation instrument.

They show why "constitutional" constraints on the policy instruments may be desirable even though they appear inefficient from a standard point of view. Their justification lies in the limitations they impose on the capacity of politicians to distribute rents. For instance, given the delegation of environmental policy to political majorities, a comparison is made between restricting majorities to choose a single pollution level, a typical command and control regulation, and letting them choose a policy consisting in choosing a menu of pollution-transfer pairs, a typical incentive regulation. Boyer and Laffont characterize the conditions under which the higher discretion associated with the second policy is compensated by its greater efficiency potential. Other instrument choices are also investigated. The results are that in general the larger the social cost of public funds and the greater the variability of economic variables are, then the more valuable flexibility is and the greater the delegation of authority to politicians should be. However, the thinner the majority or the larger the informational rents are, then the more the politicians objectives are biased away from maximizing social welfare, providing justification for cruder environmental policies that leave politicians or regulators less discretion.

A major problem arising in regulatory framework is the possibility of collusion and capture of the regulator by the regulatees. Given that this possibility is common rather than exceptional, there will be a cost to be incurred to prevent such collusion or capture when the assumption of a 
benevolent regulator is relaxed. One such prevention strategy is to split the regulatory tasks among different regulators. This strategy to counter the regulators' discretionary capability to develop wasteful activities will generate at the same time an administrative cost and a cost in terms of reduced coordination. Laffont and Martimort (1999) show that competition between regulators relaxes collusion-proofness constraints and makes the regulatory regime more efficient in terms of social welfare.

\section{Liability versus regulation}

The law and economics literature has focused predominantly upon the role of legal institutions and common law rules in achieving efficiency and distributive goals, ${ }^{32}$ in particular in the area of environmental policy. ${ }^{33}$ But relatively little attention has been given to a comparative institutional analysis between different systems.

Liability system and regulation can be compared considering the common objectives of deterring degradation and compensating victims of environmental harms: ex ante giving the incentive to precautions and controlling the environmental risk, ex post covering the costs and compensating for the damage. The authorities responsible for meeting these objectives are the courts that can assign liability, and the regulatory agencies that fix standards and check their compliance.

In a (strict) liability system the victim files an action claiming a causal link between the defendant's conduct and the plaintiff's injury or disease. Strict liability is typically applied to risks created by abnormally hazardous activities against defendants for all injuries caused by their conduct. This system has the advantage of internalizing environmental risks both from the

\footnotetext{
${ }^{32}$ See Calabresi (1970), Landes and Posner (1987), Shavell (1987).
} 
incentive and the compensation points of view. On the other hand, it has many disadvantages. First, the system relies upon a case-by-case adjudication system. Second, there may be problems in determining the causal link. Third, it may lead to inconsistent verdicts, generate long delays in court proceedings and may be more profitable to lawyers and experts than to the victims.

The regulation system is characterized by a centralized structure. Its advantages are based on the fact that it is well-suited to set a control relying upon standards: centralized search facilities, continual oversight of problems and a broad array of regulatory tools can make the regulation system capable of systematically assessing environmental risks implementing a comprehensive set of policies. On the other hand, regulatory agencies may not be well adapted to the nature of the underlying regulatory problems. Moreover, centralized command structure with specialist decisions can be subject to political pressure and to capture by the regulatees and to collusion under different forms.

As defined in Rose-Ackerman (1991, p. 54), "Statutory regulation, unlike tort law, uses agency officials to decide individual cases instead of judges and juries; resolves some generic issues in rulemakings not linked to individual cases, uses nonjudicialized procedures to evaluate technocratic information, affects behavior ex ante without waiting for harm to occur, and minimizes the inconsistent and unequal coverage arising from individual adjudication. In short, the differences involve who decides, at what time, with what information, under what procedures, and with what scope".

The main differences between the liability system and the regulation system are summarized in TABLE 2.

\footnotetext{
${ }^{33}$ See Polinsky (1980), Landes and Posner (1984), Tietenberg (1989), Kornhauser and Revesz (1994).
} 
TABLE 2

\begin{tabular}{|c||c|c|}
\hline \multirow{2}{*}{ CHARACTERISTICS } & LIABILITY SYSTEM & REGULATION SYSTEM \\
\hline \hline \multirow{2}{*}{ ACTORS } & Private parties (not always) & Public Authorities \\
\hline \hline ACTIONS & Suits & Fixing standards \\
EFFECTS & and controls \\
\hline \hline STRUCTURE & deterrent effects & Direct way to modify \\
\hline \hline FOCUS & Decentralized & Centralized \\
\hline \hline INFLUENCE & Parties in the suits & Whole population \\
\hline \hline
\end{tabular}


Shavell (1984) suggests four determinants for comparing different systems. The first determinant is the difference in know-how between private parties and the regulatory authority. It may relate to the benefits of activities, the cost of reducing risks, and the probability and the severity of accidents. It clearly could happen that the nature of the activities carried out by the firms is such that the private parties have better knowledge of the benefits, of the risks involved and of the cost of reducing risks. In such a case a liability system is better because it makes the private parties the residual claimants of the control of risks. The less informed regulator could overestimate the risks (probability and/or severity) and impose too stringent standards or could underestimate the value of the activities or the cost of reducing risk. But of course, it may also happen that the regulator has better knowledge because of the possibility of centralizing information and decisions, in particular when knowledge of risks requires special replicable and reusable expertise. It has the advantage of committing public resources to produce public knowledge. In such a case, direct regulation is likely to be better.

A second determinant is the limited capacity of private parties to pay the full costs of an accident, either because of limited liability or of insufficient assets. A traditional liability regime does not provide private parties with proper incentives for care. A regulatory system can impose directly or indirectly the proper decisions on the firms. So, the greater the probability or the severity of an accident are and the smaller the assets of the firm are relative to the potential damages, then the greater the appeal of regulation.

Clearly, a liability system can be linked with a compulsory insurance for the losses in excess of the assets of the firm. Under significant informational problems, moral hazard and/or adverse selection, the problem of insufficient incentives for care remains. Although the compulsory 
insurance provision would provide sufficient resources for cleaning-up and for compensating victims, the number of accidents would be inefficiently large unless the insurer has the ability to monitor and control the care activities of the firms. A similar alternative would be an extended liability regime that imposes strict, joint and several liability on all the deep-pocket stakeholders (suppliers, partners and financiers) of the firm.

The third determinant is the likelihood with which the responsible parties would face a legal suit for harm done. This problem is particularly present in environmental risks: in many cases the victims are widely dispersed with none of then motivated to initiate a legal action, harm may appear only after a long delay, and specifically responsible polluters may be difficult to identify. Compared with a regulatory system, the liability system is more uncertain and provides lower incentives for risk control.

The fourth determinant is the level of administrative expenses incurred by the private parties and the public. The cost of a liability system includes the cost of efforts, the legal expenses, the public expenses for maintaining legal institutions. The cost of the regulatory system includes the public expenses for maintaining the regulatory agencies and the private costs of compliance. The advantages of the liability system is here that legal costs are incurred only if a suit occurs and, if the system works well in the sense that there are incentives for choosing the efficient level of care, the suits are few and therefore the costs are low. On the other hand, under regulation, the administrative costs are incurred whether or not the harm occurs because the process of regulation is costly by itself and the regulator needs to collect information about the parties, their activities and the risks. 
Considering the four determinants, Shavell (1984) concludes that administrative costs and differences in knowledge favor liability, while incapacity to pay (or limited liability) and escaping suit favor regulation. In general, a liability system is more efficient when private parties possess better information and when accident has a low probability to occur. Regulation is better when harm is usually large, is spread among many victims or takes a long time to show up, when accidents are not very rare events, and when standards or requirements are easy to find and control.

A fifth determinant can be added to the above traditional ones: the possibility of capture and collusion between the enforcers and the parties. The enforcers may be influenced by external pressure in both systems. But it seems that the courts are less likely to be captured than the regulation agencies. If the external pressures in the case considered are likely to be very strong, a system based on assignment of liability would be better than a regulatory system.

Considering the above determinants in the specific case of environmental risks, we can now try to describe a model in which the choice between an instrument or the other is represented in terms of some key-variables.

\section{Modeling the choice of instruments}

In order to compare the two policy instruments above defined, we must consider their impacts in terms of social welfare. Such an analysis must balance the social benefits from the risky activities or industries with the costs of precautionary care, the expected level of damages (probability and severity), the administrative expenses associated with the different instruments, and the social cost and benefit of the firms' economic profits derived from informational rents. 
To compare the two instruments in terms of social welfare the model should explicitly include the following crucial features: the administrative costs of the two instruments; the asymmetric information between the public regulatory authority and the firms and between the private banks and the firms regarding the level of accident preventing activities (moral hazard) effectively implemented by the firms; the efficient financial contract; and finally the possibility of capture.

Boyer and Porrini (2001a) consider a formal political economy model consider to illustrate the different conditions under which a political economy instrument operating ex post is welfare superior to another instrument operating ex ante to regulate environmental accidents. Three contexts are characterized in a principal agent paradigm. The first context corresponds to a benevolent regulator as the principal maximizing the proper social welfare function (the reference case). The second context corresponds to the case of a profit maximizing private financier as principal, subject to extended liability if and when the firms it finances go bankrupt following a catastrophic environmental accident; the financier must then pay for the total costs, clean up and compensation, of the accident not covered by the firm's assets. The third context is characterized by a captured regulator maximizing a biased social welfare function, modeled in a reduced-form fashion through an overvaluation of the firms' profits as a source of social welfare. In all three settings, the principal party (benevolent regulator, captured regulator, private financier) determines the level of care to be implemented and the level of financing of risky activities while suffering from an informational disadvantage in its relation with the firms. The following factors are explicitly considered: the differential cost between low and high levels of environmental protection activities and the associated accident probabilities, the social cost of 
public funds, the informational rent of the firm, the net profitability of the risky activities, the level of damages if an accident occurs, the bias factor in case of capture of the regulatory agency.

The main results derived by the authors are the following. A relatively large cost differential between high and low levels of care, that is a high cost of accident preventing activities, favors the 'extended lender liability' regime. In this case, the 'regulator subject to capture' regime would end up inducing too much care, or too few environmental accidents, and/or allowing the financing of too many risky activities, that is an overdevelopment of environmentally risky industries, because the social value of the additional rents or profits so allowed are not large enough to compensate for the social cost of the extra care activities. It is better in this case to have more accidents than to allow higher rents or profits.

A relatively low cost of public funds, that is an efficient non-distortionary taxation system, favors the 'regulator subject to capture' regime. In that case, the 'extended lender liability' regime would end up inducing too little care, or too many environmental accidents, and/or allowing the financing of too few risky activities, that is an underdevelopment of environmentally risky industries.

In Boyer and Porrini (2001b), additional results are derived and illustrated through a set of graphs. Again the two instruments are respectively a liability system, characterized by a strict regime of liability assignment (as in the U.S. CERCLA system and in the E.U. White Paper) and an incentive regulation system. Their results can be summarized as the follow:

- comparing the differential cost between high and low level of accident preventing activities with the cost of social funds, larger values of the cost of social funds favors the 
private financier solution, while lower values of the differential cost of care favor the regulation subject to capture regime;

- comparing the differential cost between high and low level of accident preventing activities with the magnitude of damage, larger damage favors the regulation subject to capture regime but the larger the value of the differential cost of care, the higher the critical value of damage is above which the regulation subject to capture regime is preferred;

- comparing the capture factor with the cost of social funds, larger values of the cost of social funds favor the private financier solution, while lower values of the capture factor favor the regulation subject to capture regime;

- finally, comparing the probability of high profit with the cost of social funds, larger values of the cost of social funds favor the private financier solution, while lower values of the probability of high profit favor the regulation subject to capture regime.

\section{Conclusion}

The main conclusion of our analysis is that choosing between a regulation framework and a legal framework to implement an environmental protection policy, a crucial factor in public policy evaluation, is a difficult task requiring a formal and structured analytical approach to the modeling of the social and economic interactions between different decision makers such as governments, firms, regulators and financiers. This requires balancing many factors in a social welfare accounting framework, namely the social value of the environment-risky activities, the costs of care, the cost of public funds, the possibility of regulatory capture, the asymmetric 
information position of the different actors, the net social value of the informational rents they generate, the probability and severity of accidents, the financial market efficiency. On the other hand, our results show the power of such a formal analytical approach. 


\section{REFERENCES}

Balkenborg D. (2001), "How Liable Should a Lender Be? The Case of Judgment-Proof Firms and Environmental Risk: Comment", American Economic Review, 91, 3, pp. 731-738.

Baron, D.P. (1985), "Regulation of Prices and Pollution under Incomplete Information”, Journal of Public Economics 28, pp. 211-231.

Boyd J. (2001), "Financial Responsibility for Environmental Obligations: An Analysis of Environmental Bonding and Assurance Rules", Law and Economics of Environmental Policy, Research in Law and Economics, , edited by T. Swanson, Cambridge University Press, 2001.

Boyd J., Ingberman D. (1997), “The Search of Deep Pocket: is "Extended Liability” Expensive Liability?", Journal of Law, Economics, and Organization 13, pp. 233-258.

Boyer M. (1979), "Les effets de la réglementation”, Canadian Public Policy / Analyse de Politiques 4, pp. 469-474.

Boyer M., Lewis T.R., Liu W.L. (2000), "Setting Standards for Credible Compliance and Law Enforcement", Canadian Journal of Economics 33, pp. 319-340.

Boyer M., Laffont J.J. (1996), "Environmental Protection, Producer Insolvency and Lender Liability", chapter 1 (1-29) in A. Xepapadeas (ed.), Economic Policy for the Environment and Natural Resources, Edward Elgar.

Boyer M., Laffont J.J. (1997), "Environmental Risk and Bank Liability”, European Economic Review 41, pp. 1427-1459. 
Boyer M., Laffont J.J. (1999), “Toward a Political Theory of the Emergence of Environmental Incentive Regulation”, RAND Journal of Economics 41, pp. 137-157.

Boyer M., Porrini D. (2001a), "Law versus Regulation: A Political Economy Model of Instrument Choice for Environmental Policy", pp. 249-279 in Law and Economics of Environment, edited by Anthony Heyes, Edward Elgar Pub. Ltd.

Boyer M., Porrini D. (2001b), "Modelling the choice between Regulation and Liability in Terms of Social Welfare”, mimeo, Université de Montréal and Università degli Studi de Milano.

Buchanan J.M., Tullock G. (1975), "Polluters' Profits and Political Response", American Economic Review 65, pp. 976-978.

Calabresi G. (1970), The Cost of Accident, Yale University Press, New Haven.

Cropper M.L., Oates W.E. (1992), “Environmental Economics: A Survey”, Journal of Economic Literature, XXX, pp. 1675-740.

Dasgupta, P.S., P.J. Hammond, and E.S. Maskin (1980), “On Imperfect Information and Optimal Pollution Control", Review of Economic Studies 47, pp. 857-860.

Dionne G., Spaeter S. (1998), "Environmental Risks and Extended Liability: The Case of Green Technologies", WP 98-12, École des HEC, Montréal.

Faure M. (2000), "Environmental Regulation”, pp. 443-520 in Encyclopedia of Law and Economics, edited by B. Bouckaert, G. De Geest, Edward Elgar Pub. Ltd.. 
Feess E. (1999), “Lender Liability for Environmental Harm: An Argument against Negligence Based Rules"”, European Journal of Law and Economics 8, pp. 231-250.

Feess E., Hege U. (2000), “Environmental Harm, and Financial Responsibility”, Geneva Papers of Risk and Insurance: Issue and Practice 25, pp. 220-234.

Feess E., Hege U. (2001), "Safety Monitoring, Capital Structure, and 'Financial Responsibility",, International Review of Law and Economics, pp. 220-234.

Gobert K., Poitevin M. (1998), “Environmental Risks: Should Banks be Liable?”, WP 98s-39, CIRANO.

Gobert K. (1999), "Responsabilité des créanciers en matière environnementale”, CIRANO.

Hahn R.W. (1990), “The Political Economy of Environmental Regulation: Towards a Unifying Approach", Public Choice 65, pp. 21-47.

Heyes A. (1996), "Lender Penalty for Environmental Damage and the Equilibrium Cost of Capital", Economica, 63, pp. 311-323.

Kornhauser L.A., Revesz R.L. (1994), "Multidefendants Settlements under Joint and Several Liability: The Problem of Insolvency”, Journal of Legal Studies 23, pp. 517-542.

Kwerel, E. (1977), "To tell the truth: Imperfect information and optimal pollution control", Review of Economic Studies 44, pp. 595-601.

Laffont J.J. (1995), "Regulation, Moral Hazard and Insurance for Environmental Risk", Journal of Public Economics 58, pp. 319-336. 
Laffont, J.J., Martimort, D. (1999), “Separation of Regulators Against Collusive Behavior”, Rand Journal of Economics 30, pp. 232-262.

Landes W., Posner R. (1984), “Tort Law as a Regulatory Regime for Catastrophic Personal Injuries", Journal of Legal Studies 13, pp. 417-434.

Landes W., Posner R. (1987), The Economic Structure of Tort Law, Harvard University Press, Cambridge.

Lewis T.R. (1996), "Protecting the Environment when Costs and Benefits are Privately Known", RAND Journal of Economics 27, pp. 819-847.

Menell P.S. (1991), “The Limitations of Legal Institutions for Addressing Environmental Risks”, Journal of Economic Perspectives 5, pp. 93-113.

Menell P.S. (1998), "Regulation of Toxic Substances", in The new Palgrave dictionary of economics and the law, edited by Peter Newman, London, MacMillan, pp. 255-263.

Noll R. (1983), “The Political Foundations of Regulatory Policy”, Journal of Institutional and Theoretical Economics 139, pp. 377-404.

Pitchford R. (1995), "How Liable Should a Lender Be?”, American Economic Review 85, pp. 1171-1186.

Pitchford R. (2001), "How Liable Should a Lender Be? The Case of Judgment-Proof Firms and Environmental Risk: Reply”, American Economic Review 91, pp. 739-745. 
Polinsky A.M. (1980), "Resolving Nuisance Disputes: The Simple Analytics of Injunctive and Damage Remedies", Stanford Law Review 7, pp. 1075-1112.

Porrini D. (2001), "Economic Analysis of Liability for Environmental Accidents", RISEC, Rivista Internazionale di Scienze Economiche e Commerciali 48, pp.189-218.

Pozzo B. (2000), “Verso una responsabilità civile per danni all’ambiente in Europa: il nuovo Libro Bianco della Commissione delle Comunità Europee”, Rivista Giuridica dell'Ambiente, pp. 623-664.

Priest G. (1987), “The Current Insurance Crisis and Modern Tort Law”, Yale Law Journal 96, pp. 1521-90.

Roberts, M.J. and M. Spence (1976), "Effluent charges and licenses under uncertainty, Journal of Public Economics 5, pp. 193-208.

Rose-Ackerman S. (1991), "Regulation and the Law of Torts", American Economic Review, Papers and Proceedings 81, pp 54-58.

Segerson K. (1996), "Issues in the Choice of Environmental Instruments", in J.B. Braden, H. Folmer, T.S. Ulen (eds.), Environmental Policy with Political and Economic Integration, Brookfield: Edward Elgar.

Segerson K., Tietenberg T. (1992), “The Structure of Penalties in Environmental Enforcement: an Economic Analysis", Journal of Environmental Economics and Management 23, pp. 179-200. 
Shavell S. (1984), "Liability for Harms versus Regulation of Safety", Journal of Legal Studies 13, pp. 357-374.

Shavell S. (1986), “The Judgment Proof Problem”, International Review of Law and Economics 6, pp. 45-58.

Shavell S. (1987), Economic Analysis of Accident Law, Harvard University Press, Cambridge.

Staton D.S. (1993), “EPA's Final Rule on Lender Liability: Lenders Beware”, The Business Lawyer 49, pp. 163-185.

Tietenberg T. (1989), "Invisible Toxic Torts: The Economics of Joint and Several Liability", Land Economics 11, pp. 305-319.

Yohe G.W. (1976), “Polluter's Profits and Political Response: Direct Control Versus Taxes: Comment", American Economic Review 66, pp. 981-982. 


\section{Liste des publications au CIRANO*}

Série Scientifique / Scientific Series (ISSN 1198-8177)

2002s-17 The Choice of Instruments for Environmental Policy: Liability or Regulation? / Marcel Boyer, Donatella Porrini

2002s-16 Asymmetric Information and Product Differentiation / Marcel Boyer, Philippe Mahenc et Michel Moreaux

2002s-15 Entry Preventing Locations Under Incomplete Information / Marcel Boyer, Philippe Mahenc et Michel Moreaux

2002s-14 On the Relationship Between Financial Status and Investment in Technological Flexibility / Marcel Boyer, Armel Jacques et Michel Moreaux

2002s-13 Modeling the Choice Between Regulation and Liability in Terms of Social Welfare / Marcel Boyer et Donatella Porrini

2002s-12 Observation, Flexibilité et Structures Technologiques des Industries / Marcel Boyer, Armel Jacques et Michel Moreaux

2002s-11 Idiosyncratic Consumption Risk and the Cross-Section of Asset Returns / Kris Jacobs et Kevin Q. Wang

2002s-10 The Demand for the Arts / Louis Lévy-Garboua et Claude Montmarquette

2002s-09 Relative Wealth, Status Seeking, and Catching Up / Ngo Van Long, Koji Shimomura

2002s-08 The Rate of Risk Aversion May Be Lower Than You Think / Kris Jacobs

2002s-07 A Structural Analysis of the Correlated Random Coefficient Wage Regression Model / Christian Belzil et Jörgen Hansen

2002s-06 Information Asymmetry, Insurance, and the Decision to Hospitalize / Åke Blomqvist et Pierre Thomas Léger

2002s-05 Coping with Stressful Decisions: Individual Differences, Appraisals and Choice / Ann-Renée Blais

2002s-04 A New Proof Of The Maximum Principle / Ngo Van Long et Koji Shimomura

2002s-03 Macro Surprises And Short-Term Behaviour In Bond Futures / Eugene Durenard et David Veredas

2002s-02 Financial Asset Returns, Market Timing, and Volatility Dynamics / Peter F. Christoffersen et Francis X. Diebold

2002s-01 An Empirical Analysis of Water Supply Contracts / Serge Garcia et Alban Thomas

2001s-71 A Theoretical Comparison Between Integrated and Realized Volatilities Modeling / Nour Meddahi

2001s-70 An Eigenfunction Approach for Volatility Modeling / Nour Meddahi

2001s-69 Dynamic Prevention in Short Term Insurance Contracts / M. Martin Boyer et Karine Gobert

* Consultez la liste complète des publications du CIRANO et les publications elles-mêmes sur notre site Internet : 
2001s-68 Serial Cost Sharing in Multidimensional Contexts / Cyril Téjédo et Michel Truchon

2001s-67 Learning from Strike / Fabienne Tournadre et Marie-Claire Villeval

2001s-66 Incentives in Common Agency / Bernard Sinclair-Desgagné

2001s-65 Detecting Mutiple Breaks in Financial Market Volatility Dynamics / Elena Andreou et Eric Ghysels

2001s-64 Real Options, Preemption, and the Dynamics of Industry Investments / Marcel Boyer, Pierre Lasserre, Thomas Mariotti et Michel Moreaux

2001s-63 Dropout, School Performance and Working while in School: An Econometric Model with Heterogeneous Groups / Marcel Dagenais, Claude Montmarquette et Nathalie Viennot-Briot

2001s-62 Derivatives Do Affect Mutual Funds Returns : How and When? / Charles Cao, Eric Ghysels et Frank Hatheway

2001s-61 Conditional Quantiles of Volatility in Equity Index and Foreign Exchange Data / John W. Galbraith, Serguei Zernov and Victoria Zinde-Walsh

2001s-60 The Public-Private Sector Risk-Sharing in the French Insurance "Cat. Nat. System" / Nathalie de Marcellis-Warin et Erwann Michel-Kerjan

2001s-59 Compensation and Auditing with Correlated Information / M. Martin Boyer et Patrick González

2001s-58 Resistance is Futile: An Essay in Crime and Commitment / M. Martin Boyer

2001s-57 The Unreliability of Output Gap Estimates in Real Time / Athanasios Orphanides et Simon van Norden

2001s-56 Exact Nonparametric Two-Sample Homogeneity Tests for Possibly Discrete Distributions / Jean-Marie Dufour et Abdeljelil Farhat

2001s-55 Les coûts de la réglementation : une revue de la littérature / Robert Gagné, Paul Lanoie, Pierre-Carl Micheud et Michel Patry

2001s-54 Testing for structural Change in the Presence of Auxiliary Models / Eric Ghysels et Alain Guay

2001s-53 Environmental Regulation and Productivity: New Findings on the Porter Hypothesis / Paul Lanoie, Michel Patry et Richard Lajeunesse

2001s-52 The Aftermarket Performance of Initial Public Offerings in Canada / Maher Kooli et Jean-Marc Suret

2001s-51 Capital Structure and Risk Management / Karine Gobert

2001s-50 The Underpricing of Initial Public Offerings: Futher Canadian Evidence / Maher Kooli et Jean-Marc Suret

2001s-49 How Innovative Are Canadian Firms Compared to Some European Firms? A Comparative Look at Innovation Surveys / Pierre Mohnen et Pierre Therrien

2001s-48 A Tale of Two Ports / Ngo Van Long et Kar-yiu Wong

2001s-47 Wage Policy of Firms: An Empirical Investigation / Stéphanie Lluis

2001s-46 Forecasting Some Low-Predictability Time Series Using Diffusion Indices / Marc Brisson, Bryan Campbell et John W. Galbraith

2001s-45 The Importance of the Loss Function in Option Pricing / Peter Christoffersen et Kris Jacobs 